\title{
Evaluation of Smile Line in Relation to Age among Saudi Population in Asser Region
}

\author{
${ }^{1}$ Mohammed Ali AlQarni, ${ }^{2}$ Raid A Almnea, ${ }^{3}$ Waleed S Asiri, ${ }^{4}$ Khalid D Alhendi, ${ }^{5}$ Nabeeh A AlQahtani
}

\begin{abstract}
Introduction: Dentofacial appeal and smile are vital to a person's psychosocial well-being. The 'smile line' is commonly used as a parameter to evaluate and categorize a person's smile. This study was undertaken to determine the parameters for an objective evaluation of smiles and to assess the prevalence of various smile determining parameters in relation to age among Saudi population in Asser region.
\end{abstract}

Materials and methods: A cross-sectional survey was designed. A total of 162 study samples participated in the study. A pre-designed proforma was used to evaluate malocclusion which consisted-demographic details, smile line, gingival line, incisal line, lower lip to incisal line, buccal corridor, facial midline and dental midline, shade for upper central incisors and shade for upper lateral incisors.

Results: The mean age of study participants were $27.07 \pm$ 9.76 years. Majority of the participant, i.e. $52 \%$, had average smile line and $9.3 \%$ had very high smile line. $64.8 \%$ of the study participants had normal gingival line. Only $2.5 \%$ had over, incisal line whereas 77.2 had normal incisal line. Majority $(88.3 \%)$ of the participants had normal lower lip to incisal line. $44.4 \%$ had small buccal corridor.

Conclusion: There is scientific evidence that a certain smile line/tooth arrangement is the most common parameter which can be applied for treatment planning purposes. These results underline the importance of the smile line when restoring a patient's intraoral harmony. The clinician should aim for these parameters for an esthetic and functional balance.

Keywords: Smile line, Saudi, Prevalence of malocclusion.

How to cite this article: AIQarni MA, Almnea RA, Asiri WS, Alhendi KD, AIQahtani NA. Evaluation of Smile Line in Relation to Age among Saudi Population in Asser Region. World J Dent 2014;5(3):157-161.

Source of support: Nil

Conflict of interest: None

\footnotetext{
${ }^{1}$ Dean, ${ }^{2-4}$ Intern, ${ }^{5}$ Assistant Professor

${ }^{1}$ Department of Restorative Dental Sciences, College of Dentistry, King Khalid University, Abha, Saudi Arabia

${ }^{2-4}$ Internship Program, College of Dentistry, King Khalid University, Abha, Saudi Arabia

${ }^{5}$ Division of Periodontics, Department of Preventive Dental Sciences College of Dentistry, King Khalid University, Abha, Saudi Arabia

Corresponding Author: Mohammed Ali AIQarni, Vice Dean Department of Restorative Dental Sciences, College of Dentistry King Khalid University, Abha 61471, PO Box 3263, Saudi Arabia Phones: 966554155126, 966172418047, e-mail: maalqarny@ kku.edu.sa
}

\section{INTRODUCTION}

Dentistry has encountered a change from attention on restoration to elective corrective treatment. ${ }^{1,2}$ Although dental experts are subjected to the same natural patterns and media viewpoints, instructive encounters may predispose a clinician's esthetic inclination far from those of the general public. ${ }^{2-4}$ Clinicians are committed to comprehend excellence, amicability, function, and extent as seen by public opinion when arranging treatment. ${ }^{2,5}$ Dentofacial appeal is especially vital to a person's psychosocial well-being. . $^{2,6}$

Smiling is a standout amongst the most critical facial expressions and known as a nonverbal parameter of correspondence, communicating joy. ${ }^{6-8}$ Furthermore, an appealing smile is portrayed as a paramount apparatus to impact individuals. Overviews have checked that smiling individuals are trusted more than nonsmiling ones. ${ }^{9}$ Existing proof has additionally uncovered that facial allure, in which an alluring smile assumes a significant part, impacts voting and choices, work recruitments and other social interactions. ${ }^{6-10}$

The 'smile line' is commonly used as a parameter to evaluate and categorize a person's smile. ${ }^{11}$ The concept of smile line has been defined as 'the harmony between the curvature of the incisal edges of the maxillary anterior teeth and the upper border of the lower lip' by Frush and Fisher ${ }^{12}$ in 1985 and by Jameson ${ }^{13}$ in 2002. The importance of the confluence of the curvatures of the upper border of the lower lip and the incisal edge of the maxillary incisor to obtain an attractive smile has been discussed..$^{14}$ An 'average smile' as one that exhibits the full clinical crown of the six maxillary anterior teeth and also the premolars from frontal view. It has been also mentioned that in an average smile the incisal curve of the maxillary teeth should be parallel to the inner curvature of the lower lip. ${ }^{15}$

The upper lip position and curvature, the parallelism of the anterior incisal curve with the lower lip, the relationship between the maxillary anterior teeth and the lower lip, and the number of teeth displayed in the smile are the various characteristics that affects the smile esthetics. ${ }^{16}$ Midline diastema has been considered unesthetic by lay people. ${ }^{17,18}$

The facial midline is usually the starting point of the esthetic treatment plan. ${ }^{19}$ The location of the facial warrants two anatomical landmarks. ${ }^{20}$ The first is the nasion; the second is the base of the philtrum (Cupid's bow), in the 
center of the upper lip. A line drawn between these landmarks determines the position of the facial midline as well as the direction of the midline.

In recent years, smile analyses and attempts to include smile aspects into treatment planning have become key to orthodontic treatment success. ${ }^{21}$ The present study was attempted to assess maximum attributes of an attractive smile.

\section{MATERIALS AND METHODS}

A cross-sectional survey was designed. All study participants reporting to King Khalid University, College of Dentistry, Asser Central Hospital and Civil Hospital for Orthodontic needs were recruited as study samples. A total of 162 study samples participated in the study. Informed consent was taken from all study participants and ethical clearance was obtained from all the institutions.

The following inclusion and exclusion criteria was followed for the recruitment of the participants: Absence of incisal restorations or prosthetic crowns, abrasion, attrition or erosion; gingival retraction; gingival hyperplasia; orthodontic appliance; accentuated facial asymmetry in the superior anterior teeth and no history of facial trauma or plastic surgery in the face.

A predesigned proforma was used to evaluate malocclusion which consisted - demographic details, smile line, gingival line, incisal line, lower lip to incisal line, buccal corridor, facial midline and dental midline, shade for upper central incisors and shade for upper lateral incisors. The presence of a discrepancy between the dental and facial midlines was evaluated. The facial midline was located by drawing a line connecting two anatomical landmarks: the point between the eyebrows and the base of the philtrum in the center of upper lip. ${ }^{33}$ Type-III clinical examination as recommended by American Dental Association (ADA) specification was followed. All three examiner involved in the study were calibrated and inter examiner reliability was calculated using kappa statistics (kappa value $=0.94$ )

\section{Statistical Analysis}

The data were entered in excel 2010 and were analyzed using statistical package for social sciences 16.0. The frequency and percentage distribution of the study variables among the study participants was calculated. The association of the age with study variables was assed using Chi-square test. $\mathrm{p}$-value less than 0.05 was considered statistically significant.

\section{RESULTS}

A total of 162 participants were included in the study with a mean age of $27.07 \pm 9.76$ years (Graph 1). Table 1 shows the frequency distribution of the study parameters. Majority of
Table 1: Distribution of the study variables within the study participants

\begin{tabular}{|c|c|c|c|}
\hline \multicolumn{2}{|c|}{ Study variables } & \multirow{2}{*}{$\begin{array}{l}\text { Frequency } \\
19\end{array}$} & \multirow{2}{*}{$\begin{array}{l}\text { Percentage(\%) } \\
11.7\end{array}$} \\
\hline Smile line & Low & & \\
\hline & Average & 85 & 52.5 \\
\hline & High & 43 & 26.5 \\
\hline & Very high & 15 & 9.3 \\
\hline & Total & 162 & 100.0 \\
\hline \multirow{4}{*}{$\begin{array}{l}\text { Gingival } \\
\text { line }\end{array}$} & Normal & 105 & 64.8 \\
\hline & Equal & 56 & 34.6 \\
\hline & Over & 1 & 0.6 \\
\hline & Total & 162 & 100.0 \\
\hline \multirow[t]{4}{*}{ Incisal line } & Normal & 125 & 77.2 \\
\hline & Equal & 33 & 20.4 \\
\hline & Over & 4 & 2.5 \\
\hline & Total & 162 & 100.0 \\
\hline \multirow{4}{*}{$\begin{array}{l}\text { Lower lip to } \\
\text { incisal line }\end{array}$} & Normal & 143 & 88.3 \\
\hline & Equal & 18 & 11.1 \\
\hline & Over & 1 & 0.6 \\
\hline & Total & 162 & 100.0 \\
\hline \multirow{4}{*}{$\begin{array}{l}\text { Buccal } \\
\text { corridor }\end{array}$} & None & 60 & 37.0 \\
\hline & Small & 72 & 44.4 \\
\hline & Large & 30 & 18.5 \\
\hline & Total & 162 & 100.0 \\
\hline \multirow{3}{*}{$\begin{array}{l}\text { Facial } \\
\text { midline } \\
\text { and dental } \\
\text { midline }\end{array}$} & Coincide & 102 & 63.0 \\
\hline & Not coincide & 60 & 37.0 \\
\hline & Total & 162 & 100.0 \\
\hline \multirow{5}{*}{$\begin{array}{l}\text { Shade for } \\
\text { upper } \\
\text { central } \\
\text { incisors }\end{array}$} & A & 116 & 71.2 \\
\hline & B & 46 & 28.2 \\
\hline & $\mathrm{C}$ & 0 & 0 \\
\hline & $\mathrm{M}$ & 1 & 0.6 \\
\hline & Total & 163 & 100.0 \\
\hline \multirow{5}{*}{$\begin{array}{l}\text { Shade for } \\
\text { upper } \\
\text { lateral } \\
\text { incisors }\end{array}$} & A & 105 & 64.4 \\
\hline & B & 56 & 34.4 \\
\hline & C & 1 & 0.6 \\
\hline & $\mathrm{M}$ & 1 & 0.6 \\
\hline & Total & 163 & 100.0 \\
\hline
\end{tabular}

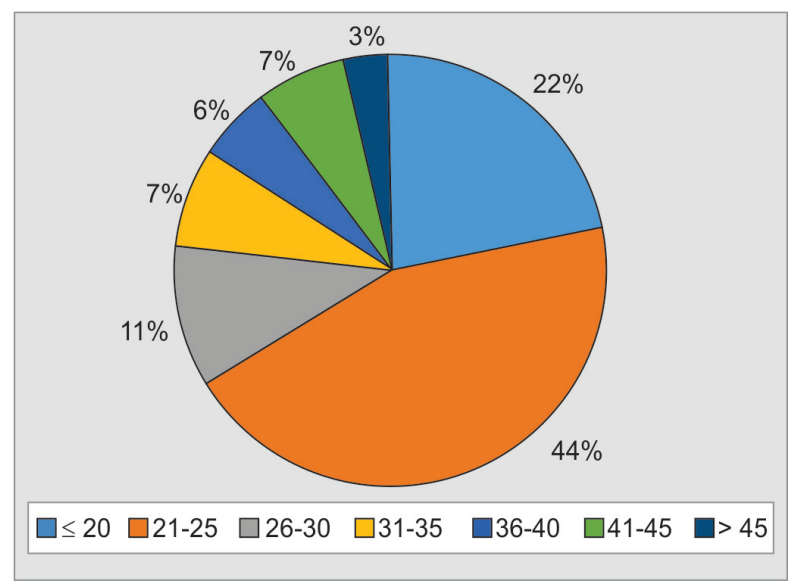

Graph 1: Age-wise distribution of the study population

the participant, i.e. $52 \%$, had average smile line and $9.3 \%$ had very high smile line (Graph 2). 64.8\% of the study participants had normal gingival line (Graph 2). Only 2.5\% 
Table 2: Association of study variables with age groups using chi-square test

\begin{tabular}{|c|c|c|c|c|c|c|c|c|c|}
\hline & & \multicolumn{7}{|c|}{ Age groups } & \multirow[t]{2}{*}{$p$-value } \\
\hline & & $\leq 20$ & $21-25$ & $26-30$ & $31-35$ & $36-40$ & $41-45$ & $>45$ & \\
\hline \multirow{5}{*}{$\begin{array}{l}\text { Smile } \\
\text { line }\end{array}$} & Low & 1 & 7 & 1 & 3 & 2 & 4 & 1 & \multirow[t]{5}{*}{0.153} \\
\hline & Average & 23 & 35 & 10 & 5 & 3 & 5 & 4 & \\
\hline & High & 7 & 22 & 6 & 3 & 4 & 1 & 0 & \\
\hline & Very high & 5 & 8 & 0 & 1 & 0 & 1 & 0 & \\
\hline & Total & 36 & 72 & 17 & 12 & 9 & 11 & 5 & \\
\hline \multirow{4}{*}{$\begin{array}{l}\text { Gingival } \\
\text { line }\end{array}$} & Normal & 26 & 49 & 12 & 5 & 6 & 4 & 3 & \multirow[t]{4}{*}{0.056} \\
\hline & Equal & 10 & 23 & 5 & 7 & 3 & 6 & 2 & \\
\hline & Over & 0 & 0 & 0 & 0 & 0 & 1 & 0 & \\
\hline & Total & 36 & 72 & 17 & 12 & 9 & 11 & 5 & \\
\hline \multirow{4}{*}{$\begin{array}{l}\text { Incisal } \\
\text { line }\end{array}$} & Normal & 28 & 59 & 12 & 9 & 8 & 7 & 2 & \multirow[t]{4}{*}{0.414} \\
\hline & Equal & 6 & 12 & 5 & 3 & 1 & 3 & 3 & \\
\hline & Over & 2 & 1 & 0 & 0 & 0 & 1 & 0 & \\
\hline & Total & 36 & 72 & 17 & 12 & 9 & 11 & 5 & \\
\hline \multirow{4}{*}{$\begin{array}{l}\text { Lower lip to } \\
\text { incisal line }\end{array}$} & Normal & 31 & 63 & 15 & 11 & 8 & 11 & 4 & \multirow[t]{4}{*}{0.509} \\
\hline & Equal & 5 & 9 & 1 & 1 & 1 & 0 & 1 & \\
\hline & Over & 0 & 0 & 1 & 0 & 0 & 0 & 0 & \\
\hline & Total & 36 & 72 & 17 & 12 & 9 & 11 & 5 & \\
\hline \multirow{4}{*}{$\begin{array}{l}\text { Buccal } \\
\text { corridor }\end{array}$} & None & 15 & 28 & 5 & 4 & 2 & 5 & 1 & \multirow[t]{4}{*}{0.903} \\
\hline & Small & 16 & 29 & 10 & 5 & 5 & 5 & 2 & \\
\hline & Large & 5 & 15 & 2 & 3 & 2 & 1 & 2 & \\
\hline & Total & 36 & 72 & 17 & 12 & 9 & 11 & 5 & \\
\hline \multirow{3}{*}{$\begin{array}{l}\text { Facial } \\
\text { midline } \\
\text { and dental } \\
\text { midline }\end{array}$} & Coincide & 21 & 46 & 10 & 8 & 6 & 8 & 3 & \multirow[t]{3}{*}{0.983} \\
\hline & $\begin{array}{l}\text { Not } \\
\text { coincide }\end{array}$ & 15 & 26 & 7 & 4 & 3 & 3 & 2 & \\
\hline & Total & 36 & 72 & 17 & 12 & 9 & 11 & 5 & \\
\hline \multirow{5}{*}{$\begin{array}{l}\text { Shade for } \\
\text { upper central } \\
\text { incisors }\end{array}$} & A & 25 & 50 & 15 & 8 & 7 & 5 & 6 & \multirow[t]{5}{*}{0.104} \\
\hline & $B$ & 11 & 22 & 2 & 3 & 2 & 5 & 1 & \\
\hline & C & 0 & 0 & 0 & 0 & 0 & 0 & 0 & \\
\hline & M & 0 & 0 & 0 & 1 & 0 & 0 & 0 & \\
\hline & Total & 36 & 72 & 17 & 12 & 9 & 10 & 7 & \\
\hline \multirow{5}{*}{$\begin{array}{l}\text { Shade for } \\
\text { upper lateral } \\
\text { incisors }\end{array}$} & $A$ & 21 & 46 & 13 & 8 & 6 & 6 & 5 & \multirow[t]{5}{*}{0.582} \\
\hline & B & 15 & 25 & 4 & 3 & 3 & 4 & 2 & \\
\hline & C & 0 & 1 & 0 & 0 & 0 & 0 & 0 & \\
\hline & $M$ & 0 & 0 & 0 & 1 & 0 & 0 & 0 & \\
\hline & Total & 36 & 72 & 17 & 12 & 9 & 10 & 7 & \\
\hline
\end{tabular}

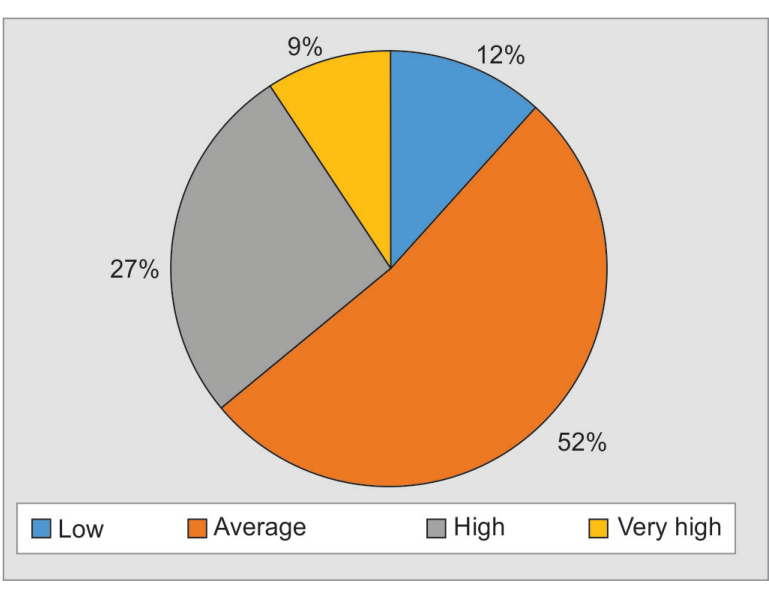

Graph 2: Distribution of the various type of smile lines

had over, incisal line whereas 77.2 had normal incisal line (Graph 2). Majority (88.3\%) of the participants had normal lower lip to incisal line. $44.4 \%$ had small buccal corridor.
Facial midline and dental midline did coincide in $63 \%$ of study population. Shade A was the most common color for the maxillary incisor teeth with 71.2 and 64.4 had A shade for upper central and lateral incisors respectively.

Table 2 shows the association of the study parameters with age of the study participants using Chi-square test. There was no statistically significant association found between age and any of the study parameters.

\section{DISCUSSION}

The smile is legitimately esteemed a significant method for nonverbal social correspondence and a sound model of facial engaging quality. Despite the fact that orthodontics is built essential with respect to occlusal connections, more stupendous consideration is currently paid to the facial style impacted by the smile. Since 1950, esthetics in orthodontics 
have for the most part been assessed by means of profile pictures because of cephalometrics and the attention on the anteroposterior measurement in malocclusions. Despite the fact that patients regularly look for orthodontia to enhance their smile, ${ }^{21-23}$ the literature predominantly emphasizes over on skeletal structures, ${ }^{21,24-27}$ which intimates that the smile gets little consideration. Quite a few criteria have been proposed in the literature to improve esthetics. These criteria are pivotal for encouraging the work of the dental practitioner and technician. ${ }^{21}$

Low smile lines are more prevalent in males while high smile lines are more common in females..$^{15,28,29}$ Desai et al analyzed the smiles of 261 people and categorized them into five age groups. ${ }^{30}$ Their most significant finding was that the height of the smile line changes with age. No subject in the 15 to 19 years age group had a low smile line, while no subject in the 50-and-over age group revealed a high smile line. Dong et al also showed that the amount of maxillary central incisor exposure during smiling decreases with age. ${ }^{16}$ However, in our study we did not find any association between age and smile line.

Moore et $\mathrm{al}^{31}$ also studied the influence of buccal corridors on smile attractiveness with lay persons as judges. They found that broad smiles were rated best, followed by medium-broad ones, medium ones, and medium-narrow ones and narrow smiles were rated least attractive. They concluded that both men and women preferred minimal buccal corridors. A similar study conducted by Dunn et al ${ }^{32}$ also corroborated these findings.

Whenever possible, the midline between the maxillary central incisors should coincide with the facial midline. In cases in which this is not possible, the midline between the central incisors should be parallel to the facial midline. But as light deviation to the right or left is still acceptable. Harmony between dentofacial characteristics should be emphasized. ${ }^{2,33-35}$

\section{CONCLUSION}

There is scientific evidence that a certain smile line/tooth arrangement is the most common parameter which can be applied for treatment planning purposes. These results underline the importance of the smile line when restoring a patient's intraoral harmony. The clinician should aim for these parameters for an esthetic and functional balance.

\section{REFERENCES}

1. Qualtrough AJ, Burke FJ. A look at dental esthetics. Quintessence Int 1994;25(1):7-14.

2. Al-Johany SS, Alqahtani AS, Alqahtani FY, Alzahrani AH. Evaluation of different esthetic smile criteria. Int J Prosthodont 2011;24(1):64-70.
3. Brisman AS. Esthetics: a comparison of dentists' and patients' concepts. J Am Dent Assoc 1980;100(3):345-352.

4. Goldstein RE. Study of need for esthetics in dentistry. J Prosthet Dent 1969;21(6):589-598.

5. Peck H, Peck S. A concept of facial esthetics. Angle Orthod 1970;40(4):284-318.

6. Shaw WC, Rees G, Dawe M, Charles CR. The influence of dentofacial appearance on the social attractiveness of young adults. Am J Orthod 1985;87(1):21-26.

7. Fradeani M. Evaluation of dentolabial parameters as part of a comprehensive esthetic analysis. Eur J Esthet Dent 2006;1(1): 62-69.

8. Matthews TG. The anatomy of a smile. J Prosthet Dent 1978;39(2):128-134.

9. Newton JT, Prabhu N, Robinson PG. The impact of dental appearance on the appraisal of personal characteristics. Int J Prosthodont 2003;16(4):429-434.

10. Passia N, Ludwigs A, Blatz M. Is the smile line a valid parameter for esthetic evaluation? A systematic literature review. Eur J Esthet Dent 2011;6(3):314-327.

11. Harati M, Mostofi SN, Jalalian E, Rezvani G. Smile line and occlusion: an epidemiological study. Dent Res J 2013;10(6): 723-727.

12. Frush JP, Fisher RD. The dynesthetic interpretation of the dentogenic concept. J Prosthet Dent 1958;8(4):558-581.

13. Jameson WS. Dynesthetic and dentogenic concept revisited. J Esthet Restor Dent 2002;14(3):139-148.

14. Hulsey CM. An esthetic evaluation of lip-teeth relationships present in the smile. Am J Orthod 1970;57(2):132-144.

15. Tjan AH, Miller GD, The JG. Some esthetic factors in a smile. J Prosthet Dent 1984;51(1):24-28.

16. Dong JK, Jin TH, Cho HW, Oh SC. The esthetics of the smile: a review of some recent studies. Int J Prosthodont 1999;12(1):9-19.

17. Rosenstiel SF, Rashid RG. Public preferences for anterior tooth variations: a web-based study. J Esthet Restor Dent 2002;14(2): 97-106.

18. Carlsson GE, Wagner IV, Odman P, et al. An international comparative multicenter study of assessment of dental appearance using computer-aided image manipulation. Int J Prosthodont 1998;11(3):246-254.

19. Spear F. The esthetic management of dental midline problems with restorative dentistry. Compend Contin Educ Dent 1999;20(10):912-914.

20. Morley J, Eubank J. Macroesthetic elements of smile design. J Am Dent Assoc 2001;132(1):39-45.

21. Durgekar SG, Nagaraj K, Naik V. The ideal smile and its orthodontic implications. World J Orthod 2010;11(3):211-220.

22. Nagaraj K, Upadhyay M, Yadav S. Impacted maxillary central incisor, canine, and second molar with 2 supernumerary teeth and an odontoma. Am J Orthod Dentofac Orthop 2009;135(3): 390-399.

23. Canavarro C, Zanella E, Medeiros PJA, Capelli J Jr. Surgicalorthodontic treatment of Class II malocclusion with maxillary vertical excess. J Clin Orthod 2009;43(6):387-392.

24. Holdaway RA. A soft-tissue cephalometric analysis and its use in orthodontic treatment planning Part I. Am J Orthod 1983;84(1): 1-28.

25. Holdaway RA. A soft-tissue cephalometric analysis and its use in orthodontic treatment planning Part II. Am J Orthod 1984;85(4):279-293. 
26. Arnett GW, Bergman RT. Facial keys to orthodontic diagnosis and treatment planning. Part I. Am J Orthod Dentofacial Orthop 1993;103(4):299-321.

27. Arnett GW, Bergman RT. Facial keys to orthodontic diagnosis and treatment planning. Part II. Am J Orthod Dentofac Orthop 1993;103(5):395-341.

28. Maulik C, Nanda R. Dynamic smile analysis in young adults. Am J Orthod Dentofac Orthop 2007;132(3):307-315.

29. Peck S, Peck L, Kataja M. Some vertical lineaments of lip position. Am J Orthod Dentofac Orthop 1992;101(6):519-524.

30. Desai S, Upadhyay M, Nanda R. Dynamic smile analysis: changes with age. Am J Orthod Dentofac Orthop 2009;136(3): 310-311.
31. Moore T, Southard KA, Casko JS, Qian F, Southard TE. Buccal corridors and smile esthetics. Am J Orthod Dentofac Orthop 2005;127(2):208-213.

32. Dunn WJ, Murchison DF, Broome JC. Esthetics: Patients' perceptions of dental attractiveness. J Prosthodont 1996;5(3):166-171.

33. Miller EL, Bodden WR Jr, Jamison HC. A study of the relationship of the dental midline to the facial median line. J Prosthet Dent 1979;41(6):657-660.

34. Beyer JW, Lindauer SJ. Evaluation of dental midline position. Semin Orthod 1998;4(3):146-152.

35. Latta GH Jr. The midline and its relation to anatomic landmarks in the edentulous patient. J Prosthet Dent 1988;59(6): 681-683. 